\title{
Evaluation of Cedrela gum as a binder and bioadhesive component in ibuprofen tablet formulations
}

\author{
Michael Ayodele Odeniyi*, Adepeju Oluwadamilare Babalola, John Oluwasogo Ayorinde
}

Department of Pharmaceutics and Industrial Pharmacy, University of Ibadan, Ibadan, Nigeria

\begin{abstract}
The compressional, mechanical and bioadhesive properties of tablet formulations incorporating a new gum obtained from the incised trunk of the Cedrela odorata tree were evaluated and compared with those containing hydroxypropylmethylcellulose (HPMC). Compressional properties were evaluated using Hausner's ratio, Carr's Index, the angle of repose, and Heckel, Kawakita and Gurnham plots. Ibuprofen tablets were prepared using the wet granulation method. Bioadhesive studies were carried out using the rotating cylinder method in either phosphate buffer $\mathrm{pH} 6.8$ or $0.1 \mathrm{M}$ hydrochloric acid media. The gum is a low viscosity polymer ( $48 \mathrm{cPs})$, and Fourier transform infrared spectroscopy revealed the presence of a hydroxyl group. $\mathrm{P}_{\mathrm{y}}$ and $\mathrm{P}_{\mathrm{k}}$ values, which are measures of plasticity, showed the gum to be significantly $(\mathrm{p}<0.05)$ more plastic than HPMC, and plasticity increased with polymer concentration. All tablet formulations were non-friable $(<1.0 \%)$, and the formulations containing the gum had a higher crushing strength $(130.95 \mathrm{~N})$ than those containing HPMC $(117.85 \mathrm{~N})$ at $2.0 \% \mathrm{w} / \mathrm{w}$ binder. Formulations incorporating the gum were non-disintegrating and had a significantly longer drug release time than those containing HPMC. At the highest binder concentration, Cedrela gum formulations adhered to incised pig ileum longer than those containing HPMC. Cedrela gum exhibited better compressive, flow and binding properties than HPMC and is suitable as a bioadhesive and for sustained release of drugs.
\end{abstract}

Uniterms: Cedrela gum/evaluation/compression properties. Cedrela gum/bioadhesive component. Tablet formulations. Hydroxypropylmethylcellulose. Ibuprofen tablets/bioadhesive studies. Bioadhesion.

\begin{abstract}
Propriedades de compressão, mecânicas e de formulações de comprimidos bioadesivos, que incorporam nova goma de mascar obtidas a partir de incisão de tronco da árvore de Cedrela odorata, foram avaliadas e comparadas com aquelas contendo hidroxipropilmetilcelulose (HPMC). Propriedades de compressão foram avaliadas usando a razão de Hausner, índice de Carr, ângulo de repouso e os gráficos de Heckel, Kawakita e Gurnham. Prepararam-se comprimidos de ibuprofeno utilizando o método de granulação a úmido. Realizaram-se estudos de bioadesividade utilizando o método de cilindro rotativo em tampão fosfato $\mathrm{pH}$ 6,8, ou meio ácido com 0,1 M de ácido clorídrico. A goma é um polímero de baixa viscosidade (48 cPs) e a espectroscopia no infravermelho por Transformada de Fourier (FTIR) revelou a presença de um grupo hidroxila. Valores de $\mathrm{Py}$ e $\mathrm{Pk}$, que são medidas de plasticidade, mostraram que a goma é significativamente $(\mathrm{p}<0,05)$ mais plástica do que HPMC e que a plasticidade aumenta com a concentração de polímero. Todas as formulações de comprimidos mostraram-se não-friáveis $(<1,0 \%)$ e aquelas contendo a goma apresentaram maior resistência ao esmagamento $(130.95 \mathrm{~N})$ do que aquelas contendo HPMC $(117.85 \mathrm{~N})$ em 2,0\% (p/p) do ligante. As formulações que incorporaram a goma eram não-desintegrantes e apesentaram tempo de liberação significativamente maior do que aquelas contendo HPMC. As formulações de goma de Cedrela aderiram à incisão de íleo de porco por tempo maior do que aquelas contendo HPMC com a maior concentração de ligante. A goma Cedrela apresentou melhor fluxo, compressão e propriedades de ligação do que HPMC e é adequada como bioadesivo e para a liberação sustentada de fármacos.
\end{abstract}

Unitermos: Cedrela goma/avaliação/propriedades de compressão. Cedrela goma/componente microadesivo. Formulações de comprimidos. Hidroxipropilmetilcelulose. Ibuprofeno/estudos bioadesivos. Bioadesão.

\footnotetext{
*Correspondence: M. A. Odeniyi. Department of Pharmaceutics and Industrial Pharmacy, University of Ibadan, 200001 - Ibadan, Nigeria. E-mail: deleodeniyi@gmail.com
} 


\section{INTRODUCTION}

As a result of the inability of most drug powders to be made into satisfactory tablets, it is often necessary to incorporate excipients, which provide adequate compressive characteristics. These excipients include diluents, binders, glidants and lubricants. Binders provide adequate mechanical properties to pharmaceutical tablet formulations by promoting the bonding properties between the different components of the powder mixture (Joneja et $a l, 1999)$. They bind powders and granules together in the wet granulation and compression processes, respectively. Binders are now being investigated for their bioadhesive properties in drug formulation.

Different compaction parameters such as measurement of ejection forces, die wall friction, axial to radial load transmission, compressibility, and deformation characteristics are used in assessing the compaction behaviour of powders and formulations. The Heckel and Kawakita equations have been found to be useful in studying the powder behaviour during compression (Odeniyi, Jaiyeoba, 2007). The mathematical equations of Heckel, Kawakita and Gurnham (Zhao et al., 2006) are used in assessing tablet properties, while the Kitazawa equation is also used to analyse the release characteristics of tablet formulations.

Many synthetic polymers, such as polyacrylic acid (PAA), polymethacrylic acid, cellulose derivatives, and polyethylene oxide, have been used as mucoadhesive drug carriers. However, these synthetic polymers are associated with undesirable mucosal irritation and, hence, the need for the development of natural polymers as bioadhesive drug delivery systems (Ameye et al., 2005).

Cedrela odorata, the most common species among the Cedrela, is widespread in seasonally dry tropical and subtropical forests. It is an important timber tree and has become naturalised in Africa and southeast Asia. While many plant gums, such as gum acacia, gum karaya, gum terminalia (Kumar et al., 2008), okra gum (Kalu et al., 2007), Delonix regia seed gum (Adetogun, Alebiowu, 2009) and Cissus gum (Adeleye et al., 2010), have been investigated, the gummy exudate of Cedrela odorata tree bark has not been studied as a binder and mucoadhesive component in pharmaceutical formulations. This study was therefore designed to determine the compressive, mechanical, bioadhesive and release properties of tablet formulations incorporating a new gum obtained from the incised trunk of the Cedrela odorata tree.

The formulations were compared with those containing hydroxypropylmethylcellulose (HPMC). Ibuprofen, a non-steroidal anti-inflammatory drug widely used to reduce pain, inflammation and stiffness caused by osteoarthritis, rheumatoid arthritis, ankylosing spondylitis or abdominal cramps associated with menstruation, has fewer side effects than similar drugs (Simon, 1997; Ong et al., 2007) and was used as the model formulation drug.

\section{MATERIAL AND METHODS}

\section{Material}

The materials used were ibuprofen powder (Sigma Chemicals, St. Louis, MO), lactose BP (DVM Veghel, Holland), HPMC (Benecel K35M, Aqualon, Hercules Inc. USA), magnesium stearate BP, (Aqualon, Hercules Inc. USA), and Cedrela gum from the incised trunk of the Cedrela odorata tree (Botanical garden, Department of Botany, University of Ibadan, Ibadan, Nigeria).

\section{Preparation of gum}

Cedrela gum was extracted from the incised trunk of a Cedrela odorata tree from the Botanical Garden at the University of Ibadan (Ibadan, Nigeria) and purified using the established methods (Berressem, 1999). Briefly, the exudate was hydrated in $0.5: 95.5(\mathrm{v} / \mathrm{v}) \mathrm{CHCl}_{3} /$ water mixture for five days with intermittent stirring; extraneous materials were removed by straining through a muslin cloth. The gum was precipitated from solution using absolute ethanol. The precipitated gum was filtered, washed with diethyl ether, and then dried in a hot air oven at $40{ }^{\circ} \mathrm{C}$ for 18 hours. The gum was pulverised using a laboratory blender and sieved, and the size fraction $<170 \mu \mathrm{m}$ was used for this study.

\section{Physicochemical properties}

The viscosity of $1 \% \mathrm{w} / \mathrm{v}$ Cedrela gum dispersed in distilled water at $25^{\circ} \mathrm{C}$ was determined using a Brookfield DV-11+Pro viscometer (Brookfield Engineering Laboratories, Middleboro, MA, USA). The Fourier transform infrared (FTIR) spectrum of Cedrela gum was obtained on an IR spectrometer (Perkin-Elmer, 2000, USA) using the $\mathrm{KBr}$ disk (2 mg sample in $200 \mathrm{mg} \mathrm{KBr}$ ). The scanning range was 400 to $4,000 \mathrm{~cm}^{-1}$.

\section{Preparation of granules}

An $80 \mathrm{~g}$ batch of ibuprofen (50\%), cornstarch $(10 \%)$, and lactose $(40 \%)$ was prepared by dry-mixing the powders for 5 minutes using a mortar and pestle; the mixed powder was transferred into an Erweka AR400 
planetary mixer, mixed for another 5 minutes, and then moistened with distilled water. Mixing was continued for 5 minutes, and the wet mass was granulated by manually passing it through a number 14 mesh sieve $(1250 \mu \mathrm{m})$. The granules were then dried in a hot oven (Gallenkamp oven) for 24 hours at $60^{\circ} \mathrm{C}$. The same procedure was used in the preparation of granules using varying concentrations of HPMC, and this was repeated for batches of granules containing Cedrela gum. Varying concentrations of the binders $(0.5 \%, 1 \%, 2 \%, 3 \%$, and $4 \%)$ were used as gum mucilage to moisten the dry-mixes instead of distilled water. The granules were stored in airtight containers.

\section{Compressional properties of the granules}

The bulk density of each formulation at zero pressure (loose density) was determined by pouring the granules into a $50 \mathrm{ml}$ glass measuring cylinder with a diameter of $24 \mathrm{~mm}$ through a funnel at an angle of $45^{\circ}$. Determinations were made in triplicate. The relative density (D) of each formulation was obtained from the ratio of the loose density to its particle density.

The angle of repose of the granules was determined by the fixed funnel method (Panda et al., 2008). The bulk and tapped densities were determined by weighing $2 \mathrm{~g}$ (W) of granules into a $10-\mathrm{mL}$ measuring cylinder. After the initial volume $\left(\mathrm{V}_{\mathrm{o}}\right)$ was measured and the cylinder was tapped on a hard surface until no further change in volume was observed, the tapped volume $\left(\mathrm{V}_{\mathrm{T}}\right)$ was noted. The bulk density (BD) and the tapped density (TD) were calculated using the following formula:

$$
\begin{aligned}
& \mathrm{BD}=\mathrm{W} / \mathrm{V}_{\mathrm{o}} \\
& \mathrm{TD}=\mathrm{W} / \mathrm{V}_{\mathrm{T}}
\end{aligned}
$$

The compressibility index of the granules was determined by Carr's compressibility index

$$
\text { Carr's Index }(\%)=\frac{\mathrm{TD}-\mathrm{BD}}{\mathrm{TD}} \times 100
$$

Hausner's ratio was calculated from the ratio of the tapped density to the bulk density.

\section{Preparation of tablets}

Equal quantities ( $400 \mathrm{mg}$ ) of each of the formulation granules were accurately weighed on a Mettler Balance PC440 and compressed into tablets, using a Carver Hydraulic tablet press (Model C, Carver Inc, Menomonee Falls, Wisconsin, USA), with nine predetermined pres- sures between 28 and $226 \mathrm{MNm}^{-2}$. The $10.5-\mathrm{mm}$ die and flat-faced punches were lubricated with a $2 \% \mathrm{w} / \mathrm{v}$ dispersion of magnesium stearate in ether-ethanol (1:1) prior to each compression. Tablets obtained were stored over silica gel for $24 \mathrm{~h}$ to allow for elastic recovery and to prevent falsely low yield values. The tablets' weights and dimensions were determined to within $\pm 1 \mathrm{mg}$ and $0.01 \mathrm{~mm}$, respectively, and their relative densities (D) were calculated using the equation

$$
D=w / V_{t} \cdot \rho_{s},
$$

where $V_{t}$ is the volume of tablet $\left(\mathrm{cm}^{3}\right)$, and $\rho_{\mathrm{s}}$ is the particle density of the solid material $\left(\mathrm{g} / \mathrm{cm}^{3}\right)$.

\section{Mechanical properties}

The friability test was performed on the tablets using a DKB Friability 5026/6 (England). The crushing strength of the tablets was determined by diametral compression (Adeleye et al., 2010) using a tablet crushing strength tester made by Karnara Industrial Cooperation, Bombay. The results were taken only from tablets that split cleanly into two halves without any sign of lamination.

\section{Compression properties of tablets}

Heckel plots of $\ln (1 /(1-\mathrm{D}))$ against the applied pressure (p) were plotted for each of the binder granulations. Values of $\mathrm{K}$ and $\mathrm{A}$ were obtained from the slope and intercept, respectively. Kawakita plots of $\mathrm{P} / \mathrm{C}$ against the applied pressure, $\mathrm{p}$, were plotted for each binder granulation. Values of $a$ and $b$ were obtained from the slope and intercept, respectively. Gurnham (Gurnham et al., 1946) plots of $\ln \mathrm{P}$ versus porosity were made for the formulations. Values of $c$, which give a measure of material plasticity, were obtained from the slopes.

\section{Mucoadhesive properties of tablet formulations}

This is a modification of the method described by Kafedjiiski et al. (2005). A porcine intestinal segment was fixed, using an elastic rubber band, onto a stainless steel cylinder with the basolateral side facing the cylinder. The tablets containing the different concentrations of the gum were pressed on the apical side, and the cylinder was put into $500 \mathrm{~mL}$ of a buffer medium, $\mathrm{pH}$ 6.8 (prepared by dissolving $6.8 \mathrm{~g}$ of sodium dihydrogen orthophosphate in sufficient distilled water to produce $1000 \mathrm{~mL}$ and $\mathrm{pH}$-adjusted using 10\% sodium hydroxide solution on a $\mathrm{pH}$ meter). 
The rotation speed was set at $50 \mathrm{rpm}$. The elapsed time when the tablet detached from the mucosa was observed and recorded. The same procedure was repeated using $0.1 \mathrm{M}$ hydrochloric acid. The phosphate buffer and $\mathrm{HCl}$ were used to simulate alkaline and acidic conditions in the small intestine and stomach, respectively. The study was carried out in triplicate.

\section{Histopathological evaluation of mucosa}

The histopathological evaluations of tissues immersed in either phosphate buffer $(\mathrm{pH} 6.8)$ or $0.1 \mathrm{~N} \mathrm{HCl}$ were compared with those of tissues before adhesion. Tissue was fixed in $10 \%$ buffered formalin, routinely processed and embedded in paraffin. Sections were cut onto glass slides and stained with hematoxylin and eosin. Sections were examined under a light microscope to detect any damage to the tissue.

\section{Disintegration and release properties of tablets}

The disintegration times of the different tablets were determined using a BP of Manesty disintegration unit (Manesty Machines Ltd, Liverpool, U.K.).

In vitro drug release studies from the prepared tablets containing Cedrela gum or HPMC as binder were conducted at $37^{\circ} \mathrm{C}$ in a dissolution basket at $100 \mathrm{rpm}$. The basket containing the tablets was immersed in $900 \mathrm{~mL}$ of phosphate buffer at $\mathrm{pH}$ 7.4. Samples of $5 \mathrm{~mL}$ were withdrawn and replaced with fresh medium. The amount of ibuprofen released was determined using a UV spectrophotometer (Unico, UV2102 PC) at a wavelength of $221 \mathrm{~nm}$. The amount of drug dissolved at specific time points was plotted as percent released versus time.

\section{Statistical analysis}

Statistical analysis was performed to compare the effect of the binders on the tablet properties using ANOVA and a t-test. At $95 \%$ confidence interval, $p$ values of $\leq 0.05$ were considered significant.

\section{RESULTS AND DISCUSSION}

Cedrela gum is a low viscosity polymer (48 cPs). FTIR revealed the presence of a hydroxyl group at $3000-3500 \mathrm{~cm}^{-1}$. The angle of repose is a measure of the frictional forces between the particles of a loose powder (Emery et al., 2009). It indicates powder flow, and values less than $30^{\circ}$ represent materials with good flow properties. The values were found to be in the range of $24-27^{\circ}$ for both the Cedrela gum and HPMC formulations. Carr's index and Hausner's ratio are based on bulk and tap densities and indicate the flow properties of the materials. Granules containing the gum had similar values of Carr's index and Hausner's ratio of generally less than $17 \%$ and $1.2 \%$, respectively (Table I). Generally, materials with Carr's index of up to $16 \%$ are known to show good flow behaviour, while those above $28 \%$ indicate poor powder flow. These results show that Cedrela gum is of similar grade with HPMC in terms of good flow behaviour.

Heckel plots for the formulations showed initial curves at low pressures, which is an indication of rearrangement and particle fragmentation (Figures 1 and 2). At the later stages of compression, linearity was obtained; this indicates that the materials deform plastically. The mean yield pressure $\left(\mathrm{P}_{\mathrm{y}}\right)$ value, calculated from the slope of the curve, is an inverse plasticity parameter (Matsson, 2000) and a measure of the onset of plasticity, which indicates granule plasticity. Lower $\mathrm{P}_{\mathrm{y}}$ values were obtained for formulations containing Cedrela gum than for those containing HPMC. This suggests faster onset of plastic deformation in the Cedrela gum formulations (Table II).

The Kawakita equation is used to depict the softness of materials and is frequently used to investigate pharmaceutical powders (Denny, 2002). A linear relationship with a correlation coefficient of $>0.999$ was obtained at all binder concentrations (Figure 3). This indicates that the equation can be used to determine the deformation mechanism of the materials. $\mathrm{P}_{\mathrm{k}}$ (also an inverse plasticity parameter) is the pressure required to reduce the bed by $50 \%$ (Shivannand, Sprockel, 1992); it indicates the total amount of plastic deformation occurring in the mate-

TABLE I - Granule and flow properties of ibuprofen formulations containing Cedrela gum and HPMC as binders at 3\% w/v

\begin{tabular}{lcccccc}
\hline Binder & $\begin{array}{c}\text { Mean Granule } \\
\text { size }(\mu \mathrm{m})\end{array}$ & $\begin{array}{c}\text { Bulk density } \\
\left(\mathrm{gcm}^{-3}\right)\end{array}$ & $\begin{array}{c}\text { Tapped density } \\
\text { Bulk density } \\
\left(\mathrm{gcm}^{-3}\right)\end{array}$ & $\begin{array}{c}\text { Angle of } \\
\text { Repose }\left(^{\circ}\right)\end{array}$ & $\begin{array}{c}\text { Hausner's } \\
\text { Ratio }\end{array}$ & $\begin{array}{c}\text { Carr's } \\
\text { Index }\end{array}$ \\
\hline Cedrela gum & 902.16 & $0.24 \pm 0.02$ & $0.72 \pm 0.04$ & $25.16 \pm 1.12$ & $1.14 \pm 0.06$ & $12.54 \pm 5.11$ \\
HPMC & 721.29 & $0.23 \pm 0.03$ & $0.77 \pm 0.01$ & $25.52 \pm 2.37$ & $1.10 \pm 0.01$ & $9.34 \pm 0.61$ \\
\hline
\end{tabular}




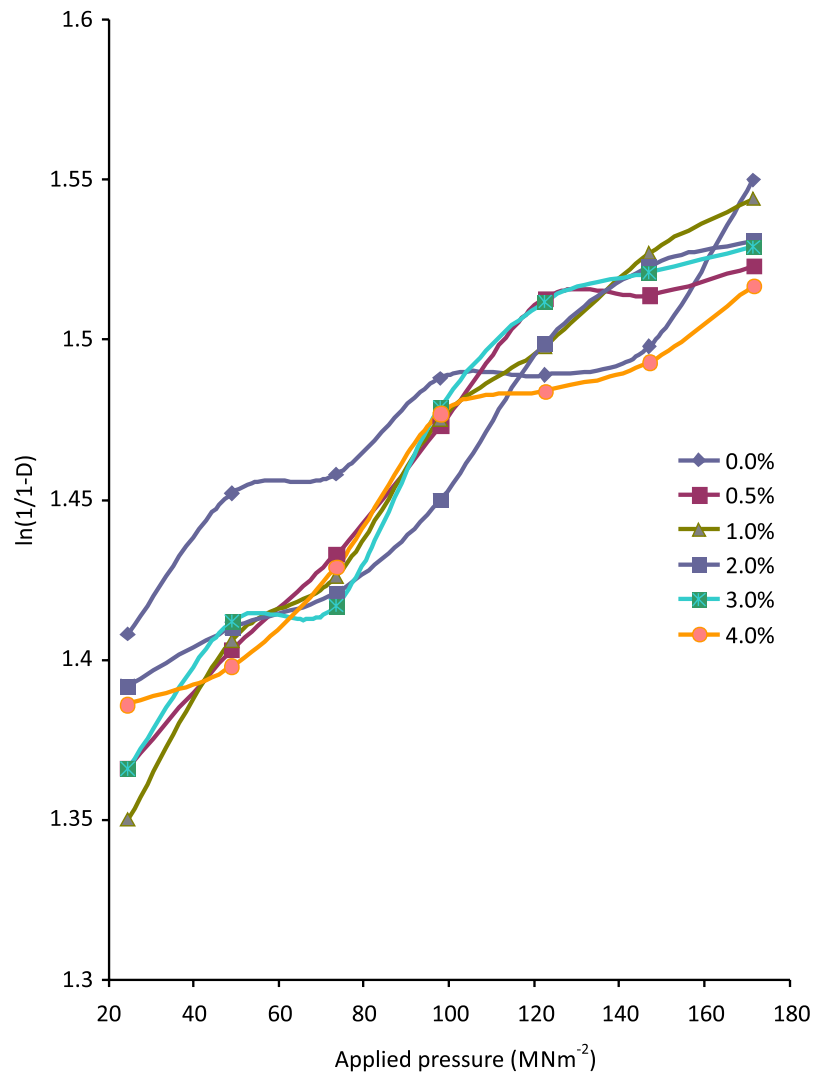

FIGURE 1 - Heckel plots for ibuprofen formulations with Cedrela gum as the binder.

rial. Lower values of $\mathrm{P}_{\mathrm{k}}$ were obtained with increasing concentrations in the tablet formulations. It is possible to obtain more information in the deformation profile of a material from the combined use of $\mathrm{P}_{\mathrm{y}}$ and $\mathrm{P}_{\mathrm{k}}$ to obtain

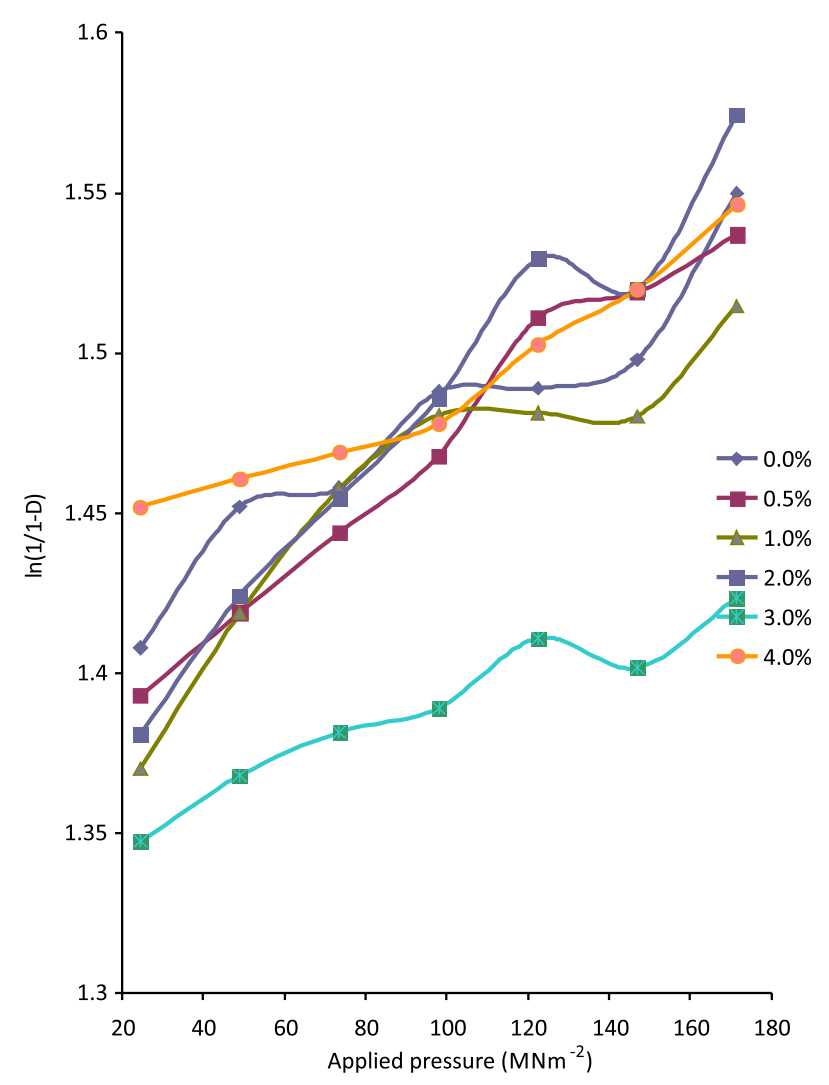

FIGURE 2 - Heckel plots for ibuprofen tablets containing hydroxypropylmethylcellulose as the binder.

conditions for optimum plasticity (Ayorinde, Itiola, 2010). Materials with low values for both $\mathrm{P}_{\mathrm{y}}$ and $\mathrm{P}_{\mathrm{k}}$ would not be expected to give any appreciable problems on any type of tableting machine during compression. $\mathrm{P}_{\mathrm{y}}$ indicates

TABLE II - Values of parameters obtained from the Heckel, Kawakita and Gurnham plots

\begin{tabular}{|c|c|c|c|c|c|c|}
\hline Type of binder & $\begin{array}{c}\text { Concentration } \\
\text { of binder }(\% \\
w / w)\end{array}$ & $\begin{array}{c}\text { Mean yield } \\
\text { pressure } \mathrm{P}_{\mathrm{y}} \\
\left(\mathrm{MN} / \mathrm{m}^{2}\right)\end{array}$ & $\begin{array}{l}\text { Relative density } \\
\text { at zero pressure } \\
\left(\mathrm{D}_{\mathrm{o}}\right)\end{array}$ & $\begin{array}{l}\text { Initial relative } \\
\text { density }\left(D_{\mathrm{i}}\right)\end{array}$ & $\begin{array}{c}\text { Pressure } \\
\text { required to } \\
\text { reduce powder } \\
\text { bed by } 50 \% \mathrm{P}_{\mathrm{k}} \\
\left(\mathrm{MN} / \mathrm{m}^{2}\right)\end{array}$ & $\begin{array}{c}\text { Effect of } \\
\text { pressure on } \\
\text { compact } \\
\text { porosity c }\end{array}$ \\
\hline \multirow[t]{5}{*}{ HPMC } & 0.5 & 10.010 & 0.205 & 0.021 & 9.79 & 0.020 \\
\hline & 1 & 12.063 & 0.191 & 0.019 & 0 & 0.023 \\
\hline & 2 & 8.278 & 0.183 & 0.018 & 9.81 & 0.016 \\
\hline & 3 & 21.552 & 0.162 & 0.017 & 9.83 & 0.021 \\
\hline & 4 & 16.103 & 0.168 & 0.016 & 0 & 0.010 \\
\hline \multirow[t]{5}{*}{ Cedrela gum } & 0.5 & 9.042 & 0.194 & 0.155 & 59.10 & 0.021 \\
\hline & 1 & 7.813 & 0.187 & 0.019 & 29.42 & 0.016 \\
\hline & 2 & 9.709 & 0.184 & 0.018 & 39.26 & 0.020 \\
\hline & 3 & 8.757 & 0.180 & 0.019 & 9.81 & 0.009 \\
\hline & 4 & 10.977 & 0.162 & 0.017 & 9.83 & 0.010 \\
\hline
\end{tabular}


the onset of plastic determination, while $\mathrm{P}_{\mathrm{k}}$ indicates the ability to deform plastically under pressure. The $D_{i}$ value is a measure of the packed initial relative density with the application of small pressures or tapping (Adetunji et al., 2006). Low values were recorded for all of the formulations. The $D_{i}$ values generally decreased with increasing binder concentrations for all formulations. The values of $\mathrm{D}_{\mathrm{i}}$ are much lower than those of $\mathrm{D}_{\mathrm{o}}$, which shows that the reduction in volume is a result of compression and that the gum impacts the plasticity of the material (Table II).

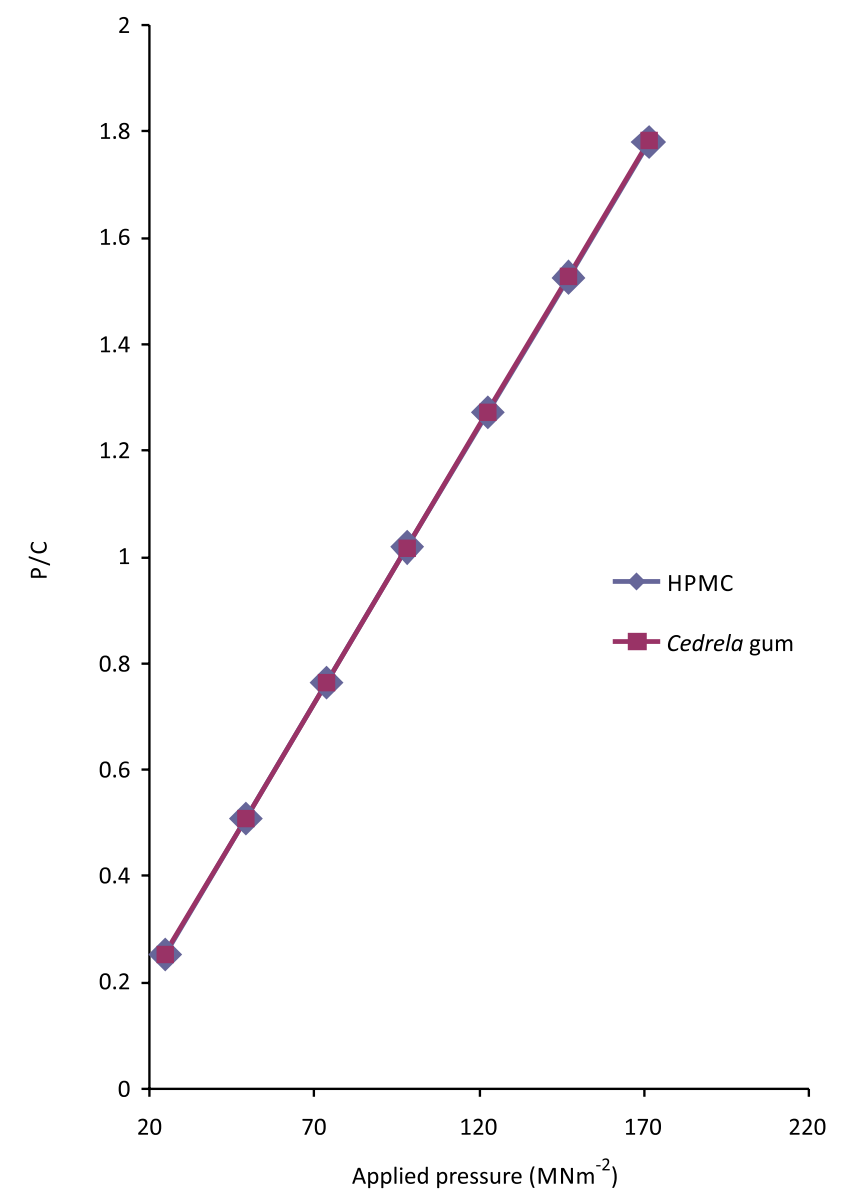

FIGURE 3 - Representative Kawakita plots for ibuprofen formulations at $3 \% \mathrm{w} / \mathrm{w}$ binder concentration.

The Gurnham equation has been investigated to study the compression process in pharmaceutical powders (Zhao et al., 2006). The equation was first introduced in chemical engineering to describe the expression of liquids from fibrous materials (Gurnham, Masson, 1946). It was proposed that any increase in pressure, expressed as a fractional increase over the existing pressure, results in a proportional increase in the apparent density of the mass:

$$
\mathrm{dP} / \mathrm{P}=\mathrm{AdD},
$$

where $\mathrm{p}$ is pressure, $\mathrm{D}$ is the apparent density (bulk density), and $\mathrm{A}$ is a constant.

The equation describes volume reduction of dry fibrous materials. Compression processes in tableting could be studied using this equation (Zhao et al., 2006):

$$
\mathrm{E}=1-\mathrm{D} / \mathrm{D}_{\mathrm{T}}
$$

where $\mathrm{E}$ is the porosity, $\mathrm{D}_{\mathrm{T}}$ is the particle density, and $\mathrm{D}$ is the bulk density.

Replacing density with porosity in the equation changes it as follows:

$$
\mathrm{E}=-\mathrm{cLN}(\mathrm{P})+\mathrm{d}
$$

Plots of $\ln$ P versus porosity give a linear relationship for powder compression. Constant $c$ (slope) is an expression of the effect of pressure on compact porosity. A high value of $\mathrm{c}$ is an indication of a strong volume reduction ability of the material as the pressure increases. A linear relationship was observed for the binders at the early stage of compression (Figure 4). This highlights the possible limitations of the equation for plasto-elastic materials such as gums.

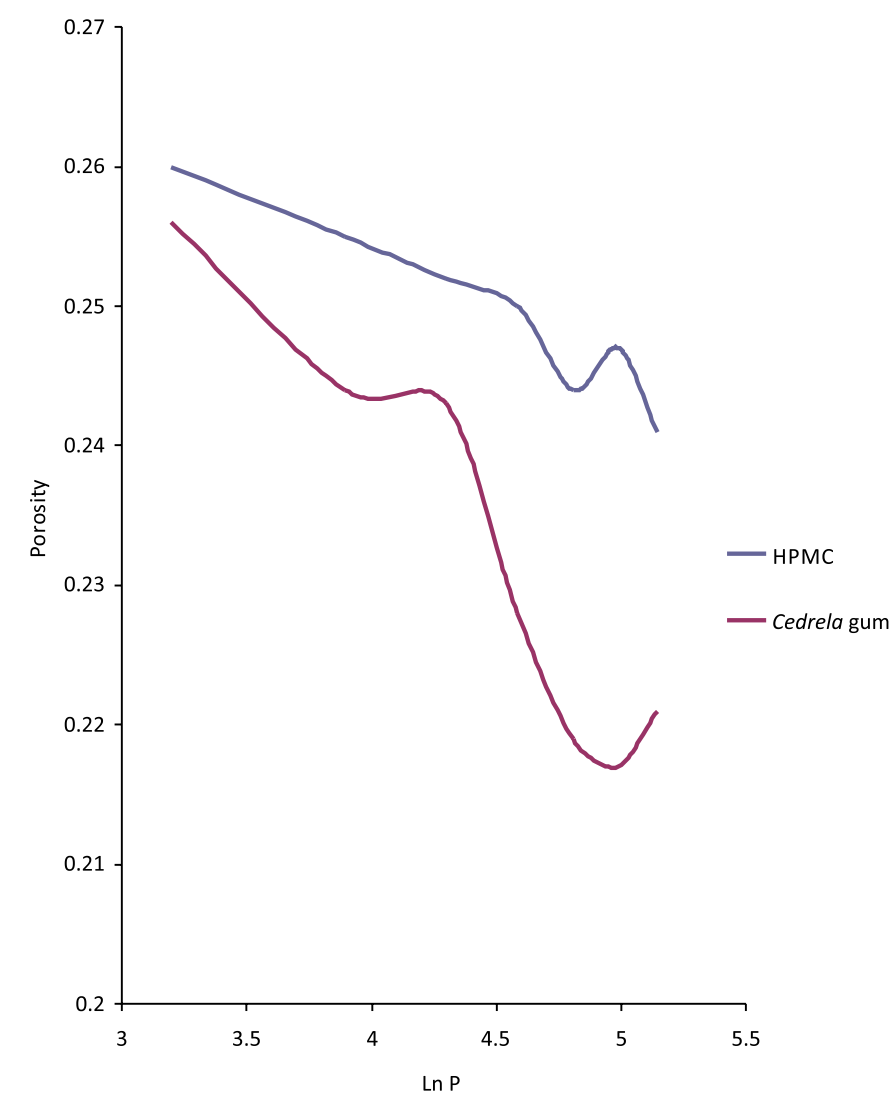

FIGURE 4 - Representative Gurnham plots for ibuprofen tablet formulations at $3 \% \mathrm{w} / \mathrm{w}$ binder concentration. 
Plots of $\ln$ P against porosity, using the Gurnham equation, gave a linear relationship only at the initial stages of compression (Figure 4). The regression coefficient values for the compression stages were observed to be low. The $\mathrm{c}$ values obtained for formulations containing Cedrela gum and HPMC were not significantly different and were generally low, within the range of $0.01-0.02$. The Gurnham equation has been used to characterise crystalline pharmaceutical powders (Zhao et al., 2006), but the results obtained from this study showed that the equation has limitations when considering amorphous materials that are plasto-elastic in nature. This most likely account for the low values of $\mathrm{c}$ obtained for both Cedrela gum and HPMC despite the good flow and compressibility properties indicated by the Carr's index, Hausner's ratio, and the Heckel and Kawakita equations, which have been used to characterise different types of pharmaceutical powders.

\section{Mechanical property}

Friability values for all the formulations were found to be less than $1.0 \%$. One of the mechanical properties used in assessing the usefulness of a new binder in a formulation is the crushing strength. This is a measure of the bond strength and ability of the tablets to withstand the stress of packaging, transportation and handling. Formulations containing Cedrela gum were found to have significantly $(\mathrm{p}<0.05)$ higher values of tensile strength than those containing HPMC. There was positive correlation between crushing strength and binder concentration (Figure 5). The concentration and type of binder have been shown to affect the tensile strength of tablets (Itiola, 1991; Ayorinde et al., 2011). The effect of binder concentration can be due to the plasto-elastic property of the binding agent; the heat produced during compaction causes melting of asperities and of the binder, which, on cooling, solidifies to form strong solid bonds between the particles. The binding agent also undergoes plastic deformation and is forced into the interparticulate spaces, thereby increasing the area of contact between the particles and forming solid bonds (Odeniyi, Jaiyeoba, 2009).

\section{Dissolution profile}

Dissolution of a drug is a prerequisite for absorption of the drug into the body and is directly related to its bioavailability. It is a standardised method for measuring the rate of drug release from a dosage form. The therapeutic effect of different formulations of the same drug depends on the rates at which the drug is released (Banakar, 1996).

The release profile of ibuprofen from the Cedrela

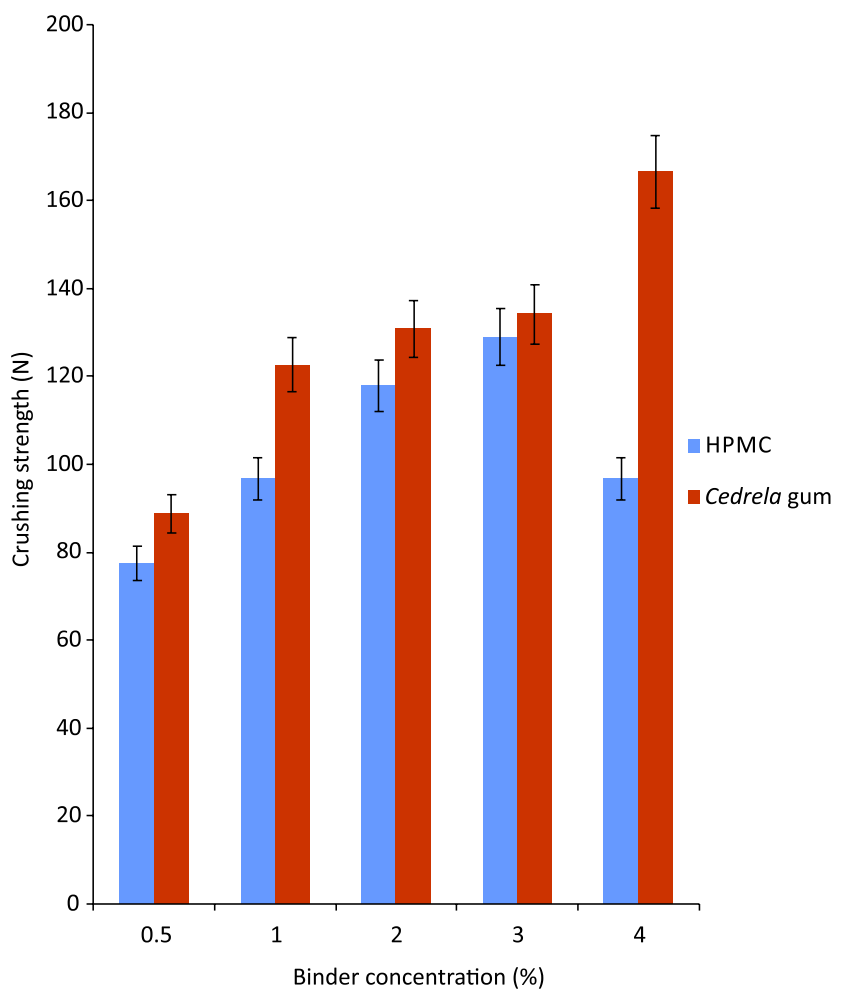

FIGURE 5 - Effect of the binder concentration on the crushing strength of ibuprofen tablet formulations.

gum tablets is shown in Figure 6 and that of the tablets incorporating HPMC is shown in Figure 7. The drug release was assessed for over 5 hours with Cedrela gum, while the release assessment of HPMC took 3 hours because the HPMC tablets dissolved faster than those incorporating the gum. Dissolution time was higher for the gum formulations than for HPMC tablets at all binder concentrations. Dissolution time increased with increasing binder concentrations, that is, the rate of release is slower at higher concentrations of both formulations. This increase in dissolution time with increasing binder concentrations could be due to the formation of a thick film of gum mucilage as the tablet comes into contact with the dissolution fluid. This film would be converted into a mucilaginous viscous barrier, which would hinder the release of drug molecules (Adetogun, Alebiowu, 2009). The release behaviour was non-linear in nature with the decreasing release rate, most likely due to diffusional resistance. The decrease in drug release rate could also be due to higher bond formation as a result of increasing binder concentrations (Odeniyi, Jaiyeoba, 2007). An increase in the hardness value of the tablets is usually accompanied by a decrease in the drug release rate due to a decrease in the porosity of the tablets. (Tabandeh et al., 2003).

The release mechanism of a drug would depend on 


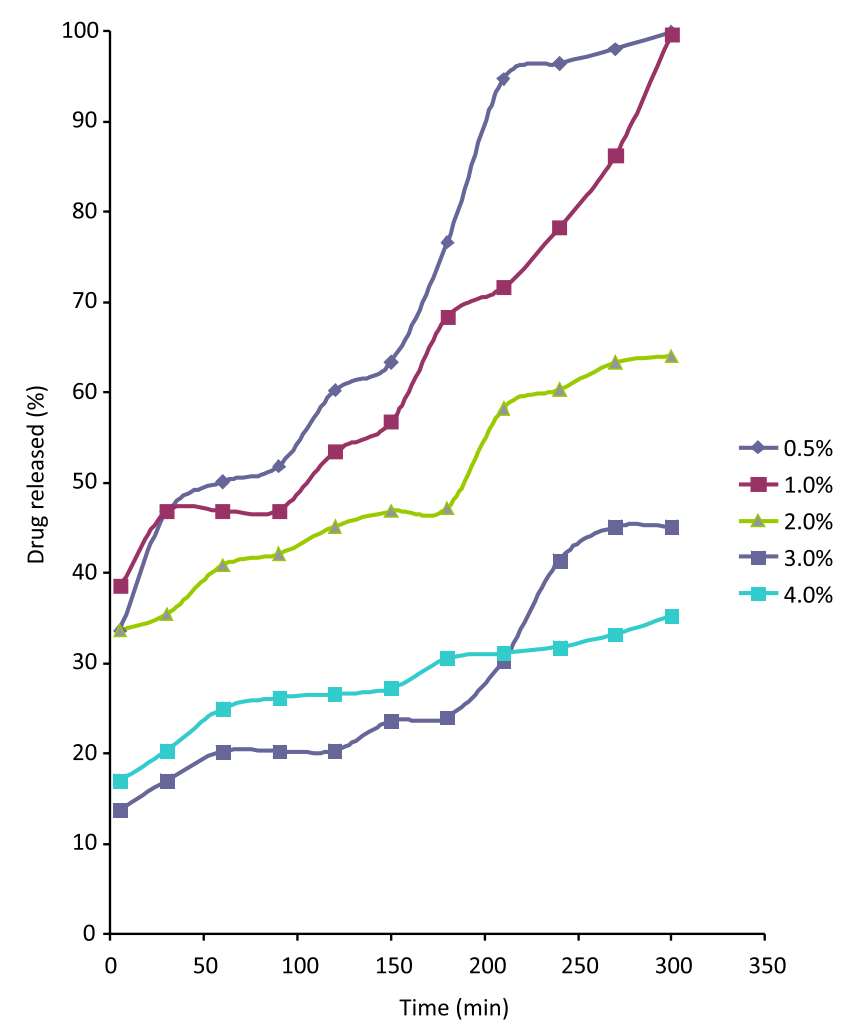

FIGURE 6 - Dissolution plot for ibuprofen released vs. time for tablets containing Cedrela gum as the binder in phosphate buffer, $\mathrm{pH} 7.4$.

the dosage form selected, $\mathrm{pH}$, nature of the drug and the polymer used. The disparity in the release rate of different classes of drugs can be attributed to the differences in their physical and chemical properties, particularly on their solubility profile (Kalu et al., 2007). The high swelling capacity of the gum and the slow rate of the Cedrela gum tablets dissolution suggest the possible use of the gum in a sustained release tablet dosage form. The data obtained from the dissolution process was further subjected to the Kitazawa et al. analysis (1975), which involves the integrated form of the Noyes-Whitney equation (1897) written as follows:

$$
\ln [C s /(C s-C)]=k t,
$$

where $C_{s}$ is the concentration of the solute at saturation, $C$ is the concentration at time $t$, and $k$ is the dissolution rate constant. Values of In $\left[C_{s} /\left(C_{s}-C\right)\right]$ were plotted versus $t$ and shown for tablets containing Cedrela gum or HPMC as binders. The data obtained are shown in Table III.

The Kitazawa plots (Figure 8) generally showed two straight regression lines of slopes $\mathrm{k}_{1}$ and $\mathrm{k}_{2}$ for the nondisintegrating tablets incorporating Cedrela gum while showing a third regression line $\mathrm{k}_{3}$ for tablets incorporating

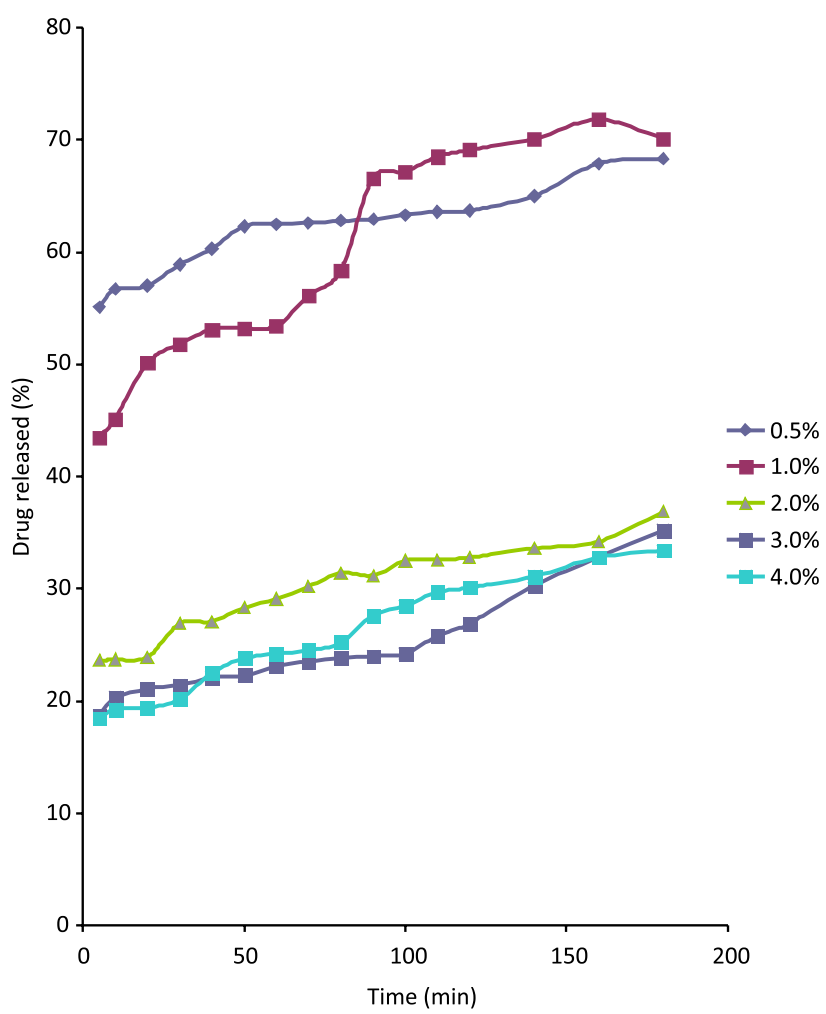

FIGURE 7 - Dissolution plot for ibuprofen released vs. time for tablets containing HPMC as the binder in phosphate buffer, $\mathrm{pH} 7.4$.

HPMC. The times at which the lines intersect are denoted $t_{1}$ and $t_{2}$. The values of $k_{1}, k_{2}, k_{3}, t_{1}$ and $t_{2}$ for the relevant samples are presented in Table III. The table shows $\mathrm{k}_{1}$ to be lower than $\mathrm{k}_{2}$ for all the formulations, implying that the dissolution rate of the drug was faster after $t_{1}$. It would appear that changes in the surface area of the dissolving particles brought about by the disintegration in the HPMC tablets and possible erosion in the Cedrela gum tablets and de-aggregation of the tablets were manifested in the increase in dissolution rate after $\mathrm{t}_{1}$. The values of $\mathrm{t}_{1}, \mathrm{k}_{1}$ and $\mathrm{k}_{2}$ for all the formulations were not significantly different.

There was no significant difference between the two polymers in adhesion time values in both media (Table IV). However, there was a general increase in adhesion time with increasing binder concentration for both polymers. This could be attributed to an increase in viscosity with increasing polymer concentrations as well as swelling properties of the incorporated binders (Bottenberg et al., 1991). The formulation containing $4.0 \% \mathrm{w} / \mathrm{w}$ Cedrela gum exhibited the highest adhesion time (Figure 9). It has been shown that at low concentrations of some polymers, the number of penetrating polymer chains per unit volume of the mucus is small and the interaction between polymer and mucus is unstable. A more concentrated polymer leads 
TABLE III - Dissolution characteristics of ibuprofen tablets (Mean $\pm \mathrm{SD}, \mathrm{N}=3$ )

\begin{tabular}{|c|c|c|c|c|c|c|}
\hline Polymer & $\begin{array}{l}\text { Binder conc. } \\
(\% \mathrm{w} / \mathrm{w})\end{array}$ & $\mathrm{t}_{1}(\min )$ & $\mathrm{t}_{2}(\min )$ & $\mathrm{k}_{1}$ & $\mathrm{k}_{2}$ & $\mathrm{k}_{3}$ \\
\hline \multirow[t]{5}{*}{ Cedrela gum } & 0.5 & $150.0 \pm 2.24$ & & $0.004 \pm 0.001$ & $0.025 \pm 0.021$ & \\
\hline & 1.0 & $270.0 \pm 1.24$ & & $0.004 \pm 0.012$ & $0.067 \pm 0.012$ & \\
\hline & 2.0 & & & $0.061 \pm 0.014$ & & \\
\hline & 3.0 & & & $0.047 \pm 0.003$ & & \\
\hline & 4.0 & & & $0.022 \pm 0.008$ & & \\
\hline \multirow[t]{5}{*}{ HPMC } & 0.5 & $50.0 \pm 1.14$ & $120.0 \pm 4.14$ & $0.004 \pm 0.001$ & $0.001 \pm 0.005$ & $0.003 \pm 0.001$ \\
\hline & 1.0 & $70.0 \pm 3.85$ & $110.0 \pm 3.18$ & $0.004 \pm 0.003$ & $0.011 \pm 0.001$ & $0.002 \pm 0.004$ \\
\hline & 2.0 & $100.0 \pm 2.75$ & & $0.001 \pm 0.001$ & $0.002 \pm 0.001$ & \\
\hline & 3.0 & $90.0 \pm 2.98$ & & $0.002 \pm 0.015$ & $0.000 \pm 0.010$ & \\
\hline & 4.0 & $80.0 \pm 3.17$ & & $0.001 \pm 0.001$ & $0.001 \pm 0.004$ & \\
\hline
\end{tabular}

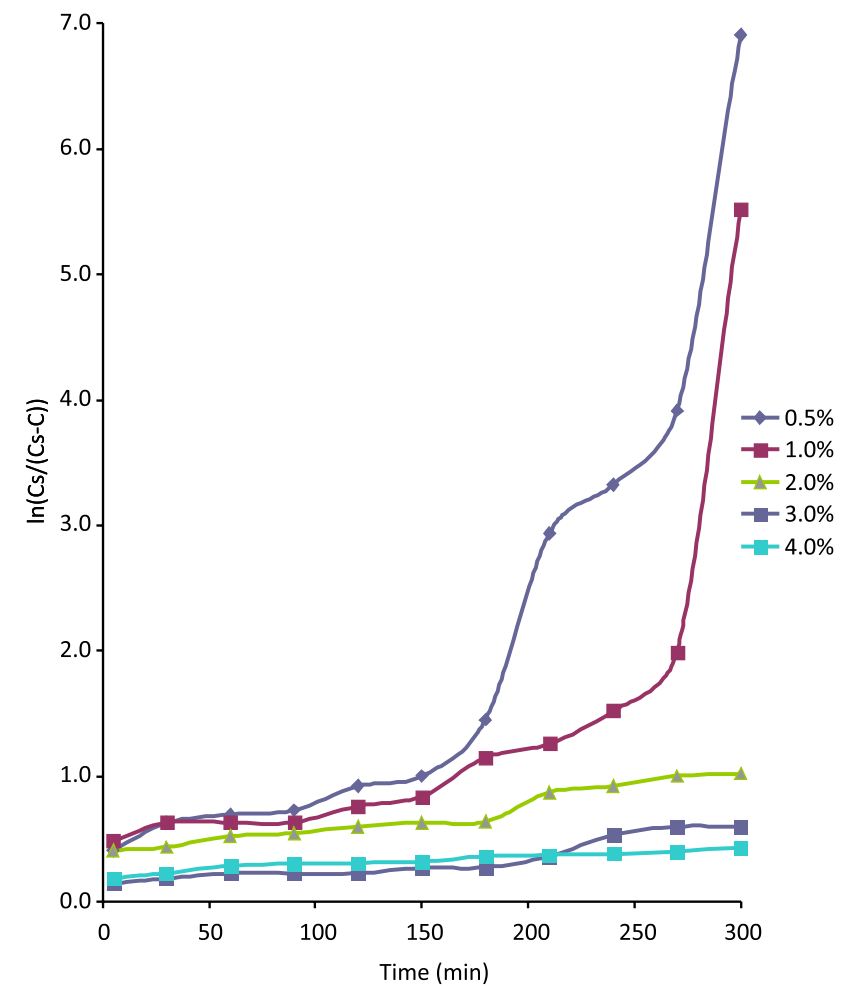

FIGURE 8 - Kitazawa plots for ibuprofen tablets containing Cedrela gum as the binder.

to longer penetrating chain length and better adhesion. Increased concentration of a bioadhesive polymer usually increases its binding potential (Park and Robinson, 1984). Further, at this concentration, Cedrela gum formulations showed a higher adhesion time in $\mathrm{pH} 6.8$ phosphate buffer due to a possible increase in hydrogen bonding effects. This indicates the potential use of the gum to target the intestine (Odeniyi et al., 2011).
TABLE IV - Adhesion time for formulations containing HPMC or Cedrela gum in $0.1 \mathrm{M} \mathrm{HCl}$ or $\mathrm{pH} 6.8$ phosphate buffer $(\mathrm{n}=3)$

\begin{tabular}{lccc}
\hline \multirow{2}{*}{ Binder } & $\begin{array}{c}\text { Concentration } \\
\text { of binder } \\
(\% \mathrm{w} / \mathrm{w})\end{array}$ & $0.1 \mathrm{M} \mathrm{HCl}$ & $\begin{array}{c}\text { Phosphate } \\
\text { buffer, } \mathrm{pH} 6.8\end{array}$ \\
\cline { 3 - 4 } & 0.0 & $0.11 \pm 0.01$ & $0.14 \pm 0.06$ \\
\hline HPMC & 0.5 & $0.16 \pm 0.03$ & $2.05 \pm 0.04$ \\
& 1.0 & $4.30 \pm 0.13$ & $3.09 \pm 0.02$ \\
& 2.0 & $3.21 \pm 0.19$ & $8.03 \pm 1.16$ \\
& 3.0 & $13.12 \pm 1.22$ & $9.15 \pm 1.03$ \\
& 4.0 & $20.08 \pm 1.16$ & $12.13 \pm 1.55$ \\
\hline Cedrela gum & 0.5 & $0.13 \pm 0.05$ & $1.31 \pm 0.02$ \\
& 1.0 & $0.25 \pm 0.02$ & $2.04 \pm 1.31$ \\
& 2.0 & $11.01 \pm 1.12$ & $11.02 \pm 2.72$ \\
& 3.0 & $16.08 \pm 1.41$ & $15.42 \pm 1.42$ \\
& 4.0 & $24.31 \pm 2.31$ & $150.08 \pm 6.82$ \\
\hline
\end{tabular}

\section{Histopathological evaluation}

Pictures of light micrographs of the intestinal mucosa prior to adhesion and after detachment of the tablets are shown in Figures 10. No damage was observed to the tissue after adhesion when examined under a light microscope. This suggests that the ibuprofen tablet formulation containing Cedrela gum has no adverse effect on the mucosal lining, making it suitable for in-vivo application.

\section{CONCLUSION}

Cedrela gum was found to be hydrophilic. The low values of $\mathrm{P}_{\mathrm{y}}$ and $\mathrm{P}_{\mathrm{k}}$ indicated that formulations with Cedre- 


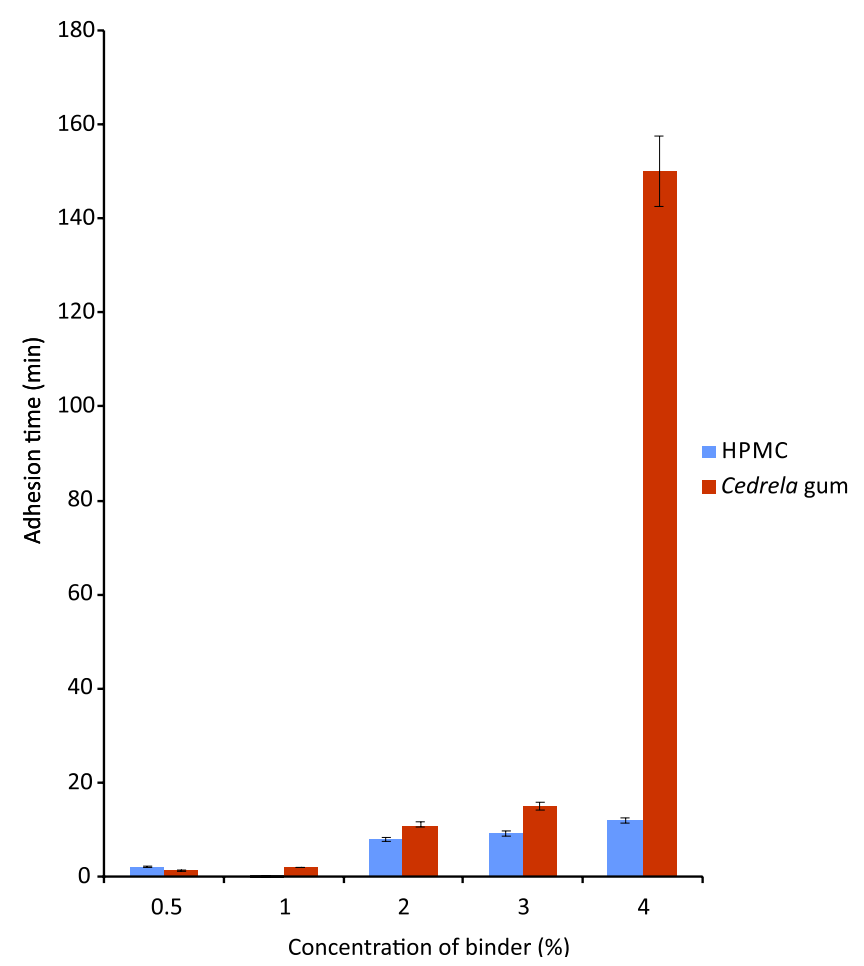

FIGURE 9 - Adhesion time on incised pig mucosa for HPMC and Cedrela gum formulations in $\mathrm{pH} 6.8$ phosphate buffer $(\mathrm{n}=3)$
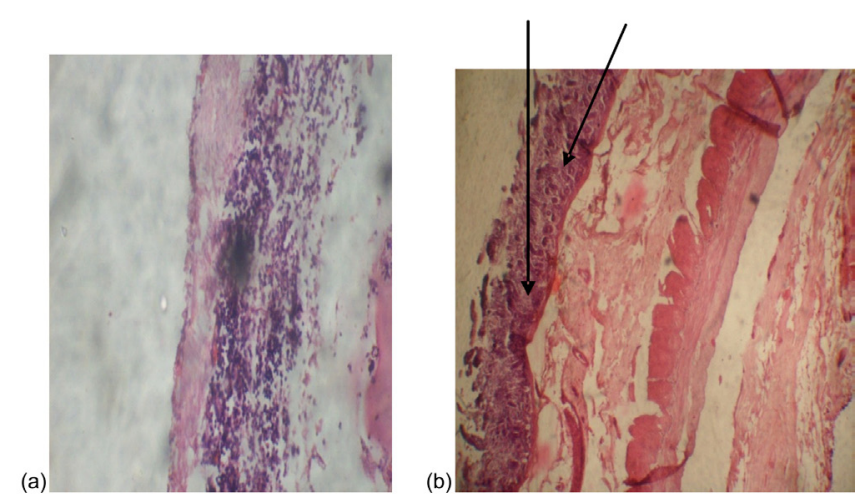

FIGURE 10 - Light micrographs of the intestinal mucosa (a) prior to application of the oral tablets and (b) after the detachment of the oral tablets. The arrows show points of attachment of the tablets.

la gum had a fast onset of plastic deformation and readily deformed plastically under pressure. The Gurnham equation was found to have limitations in characterising plastoelastic materials such as gums. Cedrela gum was found to possess a better mucoadhesive property with a prolonged adhesion time than hydroxypropylmethylcellulose at the highest polymer concentration and had no deleterious effect on the intestinal mucosa. The gum showed a slower release property as indicated by a slower dissolution rate than HPMC, indicating its potential usefulness in sustained release tablet formulations. Cedrela gum has been found to be a suitable material as a binder in tablet formulations and bioadhesive component in the dosage form.

\section{REFERENCES}

ADELEYE, A.O.; ODENIYI, M.A.; JAIYEOBA, K.T. The influence of cissus gum on the mechanical and release properties of paracetamol tablets - a factorial analysis. $J$. Basic Appl. Pharm. Sci., v.31, n.2, p.131-136, 2010.

ADETOGUN, G.E.; ALEBIOWU, G. Properties of delonix regia seed gum as a novel tablet binder. Acta Pol. Pharm, v.66, n.4, p.433-438, 2009.

ADETUNJI, O.A.; ODENIYI, M.A.; ITIOLA, O.A. Compression, mechanical and release properties of chloroquine phosphate tablets containing corn and trifoliate yam starches as binders. Trop. J. Pharm. Res. v.5, n.2, p.589-596, 2006.

AMEYE, D.; MUSA, D.; FOREMAN, P.; REMONA, J.P. Spray-dried amioca starch/carbopol 974P mixtures as buccal bioadhesive carriers. Int. J. Pharm., v.301, p.170180, 2005.

AYORINDE, J.O.; ITIOLA, O.A. Individual and interacting effects of formulation variables on the tensile strength and microbial survival in diclofenac tablets. Arch. Pharm. Res., v.33, n.3, p.395-403, 2010.

AYORINDE, J.O.; ITIOLA, O.A.; ODEKU, O.A.; ODENIYI, M.A. Influence of binder type and process parameters on the compression properties and microbial survival in diclofenac tablet formulations. Braz. J. Pharm. Sci., v.47, n.4, p.845-854, 2011.

BANAKAR, U.V.; MAKOID, M.C. Pharmaceutical issues in drug development in the drug development process. Increasing efficiency and cost-effectiveness. New York: Marcel Dekker, 1996. p.117-168.

BERRESSEM, P. The birth of new delivery systems. Chem. Br., v.35, n.2, p.29-32, 1999.

BOTTENBERG, P.; CLEYMAET, R.; DE MUYNCK, C.; REMON, J.P.; COOMANS, D.; MICHOTTE, Y.; SLOP, D. Development and testing of bioadhesive, fluoridecontaining slow-release tablets for oral use. J. Pharm. Pharmacol., v.43, n.7, p.457-464, 1991. 
DENNY, P.J. Compaction equations: a comparism of the Heckel and Kawakita equations. Powder Technol., v.127, n.3, p.162-172, 2002.

EMERY, E.; OLIVER, J.; PUGSLEY, T.; SHARMA, J.; ZHOU, J. Flowability of moist pharmaceutical powders. Powder Technol., v.189, n.2, p.409-415, 2009.

GURNHAM, C.F.; MASSON, H.J. Expression of liquids from fibrous materials. Ind. Eng. Chem., v.38, n.12, p.1309-1315, 1946.

HECKEL, R.W. Density-pressure relationships in powder compaction. Trans. Metall Soc. AIME, v.221, suppl.a, p.671-675, 1961a.

ITIOLA, O.A. Compressional characteristics of three starches and the mechanical properties of their tablets. Pharm. World J., v.8, n.3, p.91-94, 1991.

JONEJA, S.K.; HARKUM, W.W.; SKIMMER, P.E.; GUO, J.H. Investigating the fundamental effects of binders on pharmaceutical tablet performance. Drug Dev. Ind. Pharm., v.25, n.10, p.29-35, 1999.

KAFEDJIISKI, K.; WERLE, M.; FÖGER, F.; BERNKOPSCHNÜRCH, A. Synthesis and in vitro characterization of a novel poly(acrylic acid)-glutathione conjugate. J. Drug Del. Sci.Tech., v.15, n.6, p.411-417, 2005.

KALU, V.D.; ODENIYI, M.A.; JAIYEOBA, K.T. Matrix properties of a new plant gum in controlled drug delivery. Arch. Pharm. Res., v.30, n.7, p.884-889, 2007.

KITAZAWA, S.; JOHNO, I.; ITO, Y.; TERAMURA, S.; OKADA, J. Effects of hardness on the disintegration and dissolution rate of uncoated caffeine tablets. J. Pharm. Pharmacol., v.27, n.10, p.765-770, 1975.

KUMAR, S.V.; SASMAL, D.; PAL, S.C. Rheological characterization and drug release studies of gum exudates of Terminalia catappa Linn. AAPS Pharm. Sci. Tech., v.9, n.3, p.885-890, 2008.

MATTSSON, S. Pharmaceutical binders and their function in directly compressed tablets. Sweden, 2000. 62 p. [Thesis of $\mathrm{PhD}$ degree. Uppsala University].

NOYES, A.A.; WHITNEY, W.R. The rate of dissolution of solid substances in their own solutions. J. Am. Chem. Soc., v.19, n.12, p.930-934, 1897.
ODENIYI, M.A.; JAIYEOBA, K.T. Influence of hydrophilic polymers on the physicochemical stability of ascorbic acid tablets. Farmacia, v.55, n.5, p.479-490, 2007.

ODENIYI, M.A.; JAIYEOBA, K.T. Optimization of ascorbic acid tablet formulations containing hydrophilic polymers. Farmacia, v.57, n.2, p.157-166, 2009.

ODENIYI, M.A.; ATOLAGBE, F.M.; AINA, O.O.; ADETUNJI, O.A. Evaluation of mucoadhesive properties of native and modified starches of the root tubers of cocoyam (Xanthosoma sagittifolium). Afr. J. Biomed. Res. v.14, n.3, p.169-174, 2011.

ONG, C.K.S.; LIRK, P.; TAN, C.H.; SEYMOUR, R.A. An evidence-based update on nonsteroidal anti-inflammatory drugs. J. Clin. Med. Res., v.5, n.1, p.19-34, 2007.

PANDA, D.S.; CHOUDHURY, N.S.K.; YEDUKONDALU, M.; SI, S.; GUPTA, R. Evaluation of the gum of Moringa oleifera as a binder and release retardant in tablet formulation. Indian J. Pharm.Sci., v.70, n.5, p.614-618, 2008.

PARK, K.; ROBINSON, J.R. Bioadhesive polymers as platforms for oral controlled drug delivery method to study bioadhesion. Int. J. Pharm., v.19, n.1, p.107-127, 1984.

SHIVANAND, P.; SPROCKEL, O.L. Compaction behavior of cellulose polymers. Powder Technol., v.69, n.2, p.177-184, 1992.

SIMON, L.S. Biologic effects of nonsteroidal anti-inflammatory drugs. Curr. Opin. Rheumatol., v.9, n.3, p.178-182, 1997.

TABANDEH, H.; MORTAZAV, S.A.; GUILANI, T.B. Preparation of sustained-release matrix tablets of aspirin with ethylcellulose, Eudragit RS100 and Eudragit S100 and studying the release profiles and their sensitivity to tablet hardness. Iranian J. Pharm. Res., v.3, n.2, p.201-206, 2003.

ZHAO, J.; BURT, H.M.; MILLER, R.A. The Gurnham equation in characterizing the compressibility of pharmaceutical materials. Int. J. Pharm., v.317, n.2, p.109-113, 2006.

Received for publication on $08^{\text {th }}$ May 2012

Accepted for publication on $10^{\text {th }}$ January 2013 
